\title{
REINTERPRETASI KONSEP BID'AH DAN FLEKSIBILITAS HUKUM ISLAM MENURUT HASYIM ASYARI
}

\author{
Robi Sugara \\ Fakultas Syariah dan Hukum UIN Sunan Gunung Djati Bandung \\ Email : robi_sugara@gmail.com
}

\begin{abstract}
The diversity of cultures and traditions in Indonesia gives rise to religious rituals (Islam) that synergize with Shari'a. It is very ironic if these deeds carried out by Muslims in Indonesia are accused as superstitious, bid'ah, and khurafat acts, since they are not in accordance with the Qur'an and Sunnah. This condition has caused a reaction from one of traditionalists namely Hasyim Asy'ari who was very concerned in preserving local traditions which were considered has Shari'a touch. This study uses descriptive analysis methods and is based on the idea that some rituals of Indonesian Muslims cannot be separated from culture and tradition. This is considered as something new or bid'ah. Hasyim Asy'ari argues that not all new things are deviant, because even though there is no valid argument, they may still rely on Shari'a. By understanding the meaning of bid'ah as well as the traditions, it is clear that Islam is present and develops in Indonesia through wisdom-based da'wah. That way, the author feels traditions such as tahlilan, group dhikr, istighatsah, prophet's mawlid, and nisfu sya'ban must be preserved in the context of Islamic peaceful da'wah filled with wisdom in the nuances of Indonesian culture.
\end{abstract}

\section{Keywords :}

Culture, tradition, bid'ah, Hasyim Asyari, Sharia

\begin{abstract}
Abstrak
Keberagaman budaya dan tradisi di Indonesia memunculkan ritual keagamaan (Islam) yang bersinergi dengan syariat. Sangat ironis jika amaliyah yang dilakukan oleh umat Islam di Indonesia dituduh sebagai perbuatan tahayul, bid'ah, dan khurafat, karena dianggap tidak sesuai dengan al-Qur'an dan al-Sunnah. Hal ini menimbulkan reaksi dari kaum tradisionalis yaitu Hasyim Asy'ari yang sangat peduli dalam melestarikan tradisitradisi lokal yang dianggap telah bernafaskan syariat. Penelitian ini menggunakan metode analisis deskriptif penelitian serta didasarkan pada pemikiran bahwa amaliyah umat Islam Indonesia tidak lepas dari budaya dan tradisi. Hal tersebut dianggap sebagai sesuatu yang baru atau bid'ah. Hasyim Asy'ari berpendapat bahwa tidak semua hal yang baru itu berstatus sesat, karena meskipun tidak ada dalil yang sarih namun bisa jadi tetap bersandar pada syariat. Dengan memahami makna bid'ah sekaligus tradisi di atas jelas bahwa Islam hadir dan berkembang di Indonesia melalui dakwah yang bernuansa hikmah. Dengan begitu, penulis merasa tradisi-tradisi seperti tahlilan, dzikir bersama, istighatsah, maulid nabi dan nisfu sya'ban harus tetap dilestarikan dalam rangka dakwah Islam yang penuh dengan hikmah dalam nuansa budaya Indonesia.
\end{abstract}

Kata kunci :

konsep bid'ah, Hasyim Asyari, hukum Islam 


\section{Pendahuluan}

Hukum Islam merupakan aturan dasar bagi seluruh aspek kehidupan umat Islam yang bersumber dari al-Qur'an dan al-Sunnah. Sebagaimana sabda Nabi Muhammad SAW:

$$
\text { تركت فيكم امرين لن تضلؤا ما تمسكتم بكما كتب الله ؤ سنة رسوله }
$$

"Aku tinggalkan dua perkara yang tidak akan menyesatkan, kedua hal itu adalah kitab Allah dan sunnah Rasullullah" ( Riwayat Ibn Abdil Barr). ${ }^{1}$

Dua perkara yang dimaksud dalam hadist di atas ialah kitabullah (al-Our'an) dan sunnah rasul (al-hadits/sunnah). Dengan demikian umat Islam harus berpegang teguh terhadap apa yang diwasiatkan oleh Nabi Muhammad SAW dalam seluruh aspek kehidupannya. Sebagai sumber hukum bagi umat Islam seluruh dunia, Al-Qur'an dan alHadits kaya akan berbagai ajaran untuk pedoman iman dan kehidupan, hal ini menunjukkan bahwa aturan yang terdapat dalam al-Qur'an dan al-Sunnah mempunyai sifat yang flexible artinya bahwa aturan yang terdapat dalam al-Our'an dan al-Sunnah bisa masuk dalam situasi dan kondisi apapun.

Seiring berjalannya waktu dan berkembangnya pemikiran terhadap ajaran Islam menimbulkan paham keagamaan. Paham keagamaan inilah yang menjadi cikal bakal terjadinya ikhtilaf dalam agama Islam, sejarah mengatakan dengan munculnya pemahaman yang beragam terhadap ajaran Islam menimbulkan lahirnya madzhabmadzhab dan sekte-sekte dalam Islam. ${ }^{2}$

Dengan munculnya madzhab-madzhab dan sekte-sekte, sebagai akibat dari pemahaman ajaran Islam yang berbeda, hal ini melahirkan beberapa paham keagamaan yang mempunyai corak dan karakter yang berbeda pula. Sehingga tidak bisa dihindarkan adanya hal-hal baru yang berbeda dan memunculkan ikhtilaf dikalangan mereka. Hal baru yang dilakukan oleh sebagian umat Islam pada zaman dulu dan masa kini yang bersinggungan dengan budaya dan tradisi serta agama, merupakan hal-hal yang tidak ada contohnya dari rasul dan tidak termaktub dalam al-Qur'an dan al-Sunnah, sehingga hal tersebut dihukumi bid'ah.

Melihat konteks Indonesia sekarang ini, yang sangat kaya dengan keberagaman budaya dan tradisi yang menjadi identitas dari bangsa Indonesia. Sangat ironi jika amaliyah yang dilakukan oleh umat Islam Indonesia dituduh sebagai perbuatan bid'ah, tahayul, khurafat dan lain sebagainya. Bukankah hukum Islam itu bersifat universal dan

${ }^{1}$ Hadith ini diriwayatkan oleh al-Hakim dalam al-Mustadrak (no. 319), al-Daruqutni dalam al-Sunan (no. 149) dan al-Baihaqi dalam al-Sunan al-Kubra (no. 20124). Menurut Ibn 'Abd al-Bar, "Hadith ini terpelihara, dimaklumi dan masyhur daripada Nabi SAW, di sisi para ulama ianya masyhur sehingga hampir tidak memerlukan sanad...". Ibn 'Abd al-Barr (1387h), al-Tamhid lima fi al-Muwatta' min alMa'ani wa alAsanid, al-Maghrib: Wizarah 'Umum al-Awqaf wa al-Syu'un al-Islamiyyah, j 24, h. 331.

${ }^{2}$ Achmad Muhibbin Zuhri, Pemikiran K.H M. Hasyim Asy'ari Tentang Ahl AL-Sunnah Wa AL-Jamaah (Surabaya: Khalista, 2010). HIm. 1 
rahmatan lilalamin?. Kalau hukum Islam ini dikerangkeng dengan makna tekstual atau secara zdhahir yang tercantum dalam al-Quran dan al-Sunnah menunjukan bahwa hukum Islam ini bersifat kaku dan menyalahi bahwa Islam itu sebagai rahmatan lil alamin. Dengan demikian, hukum Islam yang mengatur seluruh aspek kehidupan terutama umat Islam, haruslah dimaknai secara kontekstual agar tidak menunjukan bahwa hukum Islam itu kaku dan selalu selaras dengan perkembangan zaman dan tempat umat Islam berada.

Sejarah mengatakan bahwa Islam bisa berkembang dengan pesat di Nusantara ialah dengan memasukkan nilai-nilai Islam pada setiap adat, tradisi dan budaya bangsa. Misalnya dakwah atau penyebaran agama Islam yang dilakukan oleh para Wali Songo, mereka menyebarkan Islam dengan melakukan pendekatan budaya tidak dengan memerangi budaya atau adat istiadat akan tetapi mereka menyandingkan atau menyelaraskan agar agama dan adat menjadi saling melengkapi. Adat dilengkapi agama hasilnya adalah perbuatan yang bisa sejalan dengan syariat Islam, begitupun agama dimasukkan dalam budaya. Hal ini tentunya membawa hal positif yang akan sangat bermanfaat bagi penyebaran Islam apabila Islam dikembalikan kepada esensi yang sebenarnya yaitu rahmatan lil alamin. ${ }^{3}$

Hal tersebut ternyata menimbulkan kontroversi di kalangan umat Islam sendiri, terutama mengenai ritual-ritual yang sering dilaksanakan oleh umat Islam di Indonesia. Islam yang bersifat universal dan merupakan rahmatan lilalamin (rahmat bagi seluruh alam semesta) memberikan corak atau karakter tersendiri bagi umat Islam di Indonesia.

Potret Islam Nusantara yang mengemuka dalam bentuk-bentuk pemikiran dan simbol-simbol tradisi keagamaan dalam beberapa hal berbeda dengan ekspresi Islam di Timur Tengah, yang merupakan pusat pengembangannya. Hal ini karena Islam yang normatif telah mengalami persinggungan atau berdialog dengan konteks historis dimana Islam diterapkan.

K.H Hasyim Asy'ari tokoh terkemuka sekaligus pendiri organisasi Islam Nahdlatul Ulama NU (1926) merupakan ulama yang sangat mempertahankan tradisi lokal yaitu mempertahankan tradisi masyarakat Islam Indonesia atau tradisi lokal dengan berbagai varian dalam elemen-elemen Islam yang masih sejalan dengan prinsip-prinsip Islam dengan praktik-praktik lokal, sepanjang perpaduannya memiliki landasan dan tujuan religius. Konsep Islam lokal yang tergambar dalam kontruksi pemikirannya, juga menjadi pembeda pandangan antara Islam Timur Tengah yang kental dengan Arabismenya dengan pandangan Islam pribumi.

Dalam hal ini Kiai Hasyim meletakkan unsur lokalitas yang bersifat historis secara faktual telah menghasilkan kodifikasi hukum Islam sebagai khazanah yang merupakan bagian dari Islam. Akan tetapi kalangan pembaru menyebut hal tersebut adalah sebagai bagian dari bid'ah yang tidak didapati contohnya pada masa Nabi dan para sahabatnya.

\footnotetext{
${ }^{3}$ Nurcholis Madjid, Islam Kemodernan Dan Keindonesiaan (Bandung: Mizan, 2008). HIm. 42
} 
Tetapi Kiai Hasyim tidak berhenti pada posisi pembelaan terhadap realitas keberagamaan masyarakat. la berdiri pada posisi pembaru dengan membawa karakter intelektualnya yang mengukuhkan landasan teologis bagi masyarakat islam tradisional yang sering menggunakan tasbih, tahlilan, tawassul, istighasah, peringatan maulid Nabi, kirim do'a dan sedekah untuk mayit ziarah kubur, dan lain sebagainya. ${ }^{4}$

Banyak ulama yang tidak setuju dengan keanekaragaman budaya, tradisi dan adat istiadat (kearifan lokal) dimasukkan sebagai bagian dari ajaran agama. Mereka menyebut bahwa hal yang seperti itu adalah bid'ah. Bid'ah merupakan suatu hal yang baru yang tidak pernah ada contoh dari Rasul SAW.

Paham yang menolak unsur-unsur ajaran Islam dalam suatu perbuatan yang baru dan menganggap muhadats itu sebagai suatu kesesatan dan harus dimusnahkan ialah paham wahabi. Mereka menolak seluruh kegiatan keagamaan yang tidak sesuai dengan al-Qur'an dan al-Sunnah atau yang tidak ada contohnya dari Rasul SAW, seperti ziarah kubur, peringatan maulid Nabi, talqin jenazah dan lain sebagainya sehingga harus dimusnahkan. Akan tetapi bagi Kiai Hasyim hal yang disebutkan di atas itu harus dipertahankan, karena beliau berpendapat bahwa tidak semua hal yang baru itu berstatus sesat, meskipun tidak ada dalil yang sharih namun tetap bersandar pada syariat Islam. ${ }^{5}$

Hal di atas terbukti dengan metode dakwah Kiai Hasyim yang memperhitungkan keadaan sosial dan kebutuhan masyarakat dengan tetap mempertimbangkan tradisi. Beliau mencoba mempertahankan tradisi Islam yang ada di Jawa dan tidak menghendaki adanya konfrontasi sosial dalam penduduk muslim Indonesia. Hal ini menunjukkan sikap yang elegan terhadap tradisi klasik yang sudah dibangun sejak awal oleh para pendahulu. ${ }^{6}$

Tulisan yang ini mencoba untuk memaparkan relevansi konsep bid'ah Hasyim Asy'ari dengan adat dan tradisi masyarakat Islam di Indonesia, sehingga tampak fleksibiltas hukum Islam yang berkembang di dalam umat Islam di Indonesia.

\section{Metode Penelitian}

Peneliti menggunakan metode analisis deskriptif penelitian dengan mengutamakan pengamatan terhadap gejala dan kondisi aktual di indonesia. Berkaitan dengan penelitian ini, penulis akan menganalisis dari pendapat Kiai Hasyim Asy'ari mengenai konsep bid'ahnya sehingga didapatkan satu analisis yang bersinergi dengan fleksibilitas hukum islam dalam kearifan lokal. Sumber data yang digunakan dalam penelitian ini adalah sumber primer yaitu pemikiran K.H Hasyim Asy'ari serta data sekundernya meliputi dokumen-dokumen resmi,buku-buku dan hasil karya ilmiah (makalah, tulisan),

\footnotetext{
${ }^{4}$ Ahmad Muhibbin Zuhri. Pemikiran K.H M. Hasyim Asy'ari ..., HIm. 145

${ }^{5}$ Muhibbin Zuhri. HIm. 178

${ }^{6}$ Samsul Ma'arif, Mutiara-Mutiara Dakwah K.H Hasyim Asy'ari (Jakarta: Kanza Publishing, 2011). HIm. 110-111
} 
hasil penelitian yang telah di publikasikan, dan lain-lain yang berkaitan dengan permasalahan penelitian. Teknik pengumpulan data yang digunakan dalam penelitian ini ialah dengan teknik studi kepustakaan (library research).

\section{Hasil dan Pembahasan (Konsep Bid'ah menurut K.H. Hasyim Asy'ari)}

Pemikiran teologi Hasyim Asy'ari sejalan dengan pemikiran tradisional berdasarkan formulasi al-Asy'ari dan al-Maturidi. Formulasi ini merupakan bagian dari paham Ahlu Sunnah Wal Jamaah yang berusaha menjembatani antara mereka yang mendukung kebebasan berkehendak dan yang berpedoman pada fatalisme, juga antara mereka yang mengedepankan akal yang mendasarkan pendapat mereka pada al-Quran dan alSunnah. ${ }^{7}$

Berdasarkan pemikiran teologi yang dipengaruhi paham Asy'ariyah dan alMaturidi dan tariqat mengikuti al-Ghazali, makna bid'ah menurut beliau adalah mendatangkan atau menciptakan sesuatu perkara baru dalam agama, dan meyakininya sebagai bagian dari ajaran agama. Beliau berpendapat bahwa tidak semua hal yang baru itu berstatus sesat karena meskipun tidak ada dalil yang sharih namun bisa jadi tetap bersandar pada syariat Islam. ${ }^{8}$

Menurut Sudirman ${ }^{9}$ pendapat Kiai Hasyim di atas berdasarkan pada kaidah fiqh yang menyatakan: "menjaga tradisi yang baik dan membangun inovasi yang lebih baik". Pandangan ini menunjukkan bahwa beliau yang biasa dikategorikan sebagai tradisionalis tidak menolak pembaharuan bahkan selalu berorientasi pada pembaharuan. Sikap seperti ini boleh dikata dipengaruhi oleh tasawuf, karena tasawuf tidak melihat kehidupan agama dari segi bid'ah atau tidak, tetapi lebih menekankan pada sikap manusiawi, seperti sabar, ikhlas, tawakal dan sebagainya, dan bahkan bersikap permisif terhadap kehidupan keagamaan yang berasal dari luar Islam,sehingga akan jauh dari perdebatan masalah bid'ah.

Diskursus tentang bid'ah oleh Kiai Hasyim dipersandingkan dengan sunnah secara berlawanan. Term bid'ah dipakai oleh Kiai Hasyim untuk mengidentifikasi kelompokkelompok yang tidak memiliki kesesuaian dengan parameter ahlu sunnah wal jamaah dalam konsepsinya. Mereka ini oleh Kiai disebut ahlu bid'ah. Selain itu uraian tentang bid'ah dikaitkan dengan perbedaan pandangan antara kalangan pesantren dan pembaru mengenai sejauh mana sebuah ekspresi keagamaan atau pranata-pranata baru dalam agama bisa disebut bid'ah.

Dalam rissallah ahlu sunnah wal jamaah Kiayi Hasyim banyak memberi penjelasan secara detail tentang bid'ah dan berbagai manifestasinya ditengah-tengah masyarakat.

\footnotetext{
${ }^{7}$ Lathiful Khuluq, Fajar Kebangunan Ulama : Biografi K.H. Hasyim Asyári. (Yogyakarta : LKis, 2000) hlm. 45

8 Ahmad Muhibbin Zuhri. HIm. 178

9 Muchid Muzadi, NU dalam Perspektif Sejarah dan Ajaran: Refleksi 65 Tahun Ikut NU (Surabaya: Khalista, 1994), h. 26.
} 
Terutama setelah diskursus yang mengemuka banyak dipersinggungkan dengan praktikpraktik keberagamaan muslim tradisional di Jawa, seperti diantaranya tahlilan, dzikir bersama, istighatsah, maulid nabi dan nisyfu sya'ban. ${ }^{10}$

Menurut Kiayi Hasyim, bid'ah dapat diartikan mendatangkan atau menciptakan suatu perkara baru di dalam agama, dan meyakininya sebagai bagian dari ajaran agama, padahal perkara tersebut sebenarnya tidak menjadi bagian dari ajaran agama. ${ }^{11}$ Dalam mendefinisikan pengertian bid'ah, Kiayi Hasyim menggunakan dua hadist sebagai basis legitimasi kebutuhan memberikan rumusan tersendiri tentang bid'ah. Yang pertama, teks yang menegaskan "barang siapa yang menciptakan sesuatu yang baru dalam urusan agama Kami, yang urusan tersebut bukan dari urusan agama, maka ia tertolak". ${ }^{12}$ Sementara teks yang kedua menyebutkan "dan setiap yang baru datang adanya adalah bid'ah". ${ }^{13}$ Kiai Hasyim menggunakan dua hadist tersebut sebagai pintu masuk untuk membuktikan kepada publik Islam bahwa "tidak semua perkara yang baru adanya adalah bid'ah dan sesat". Berbeda dengan sebagian kalangan yang menganggap semua yang baru itu adalah bid'ah dan bid'ah adalah sesat. Bagi Kiayi Hasyim tidak semua muhadast berstatus bid'ah karena meskipun tidak ada dalil yang jelas, namun bisa jadi tetap bersandar pada syariat. Sandaran dimaksud dapat digali dengan berbagai pendekatan atau metodologis misalnya dengan mekanisme penganalogian (qiyas). Hal ini berarti, penerjemahan terhadap teks-teks otoritatif (hadist) tentang bid'ah harus menggunakan pendekatan yang lebih menyeluruh atau tidak hanya tekstual semata.

Menurut beliau: ${ }^{14}$

"Setiap perkara yang baru datang harus ditelusuri secara menyeluruh, sebelum diputuskan status hukum kebid'ahannya. Jika sebuah perkara yang baru datang (muhadatsh) memiliki sandaran syari'at, baik secara langsung maupun setelah diteliti melalui berbagai pendekatan kontekstual, maka hal itu tidak berstatus bid'ah. Sebaliknya muhadhath baru disebut bid'ah, ketika ia tidak memiliki persinggungan dengan syari'at sedikitpun."

Selain itu, kajian terhadap bid'ah pun harus menyertakan kajian terhadap berbagai pendapat yang ada secara komprehensif. Ketika terdapat dua pendapat atau lebih dalam satu perkara yang baru datang (muhdathah), tidak dengan serta merta mengambil pendapat yang membid'ahkan muhdhathah tersebut. Sebaliknya, berbagai pendapat harus diuji atau ditarjih lebih dulu, dan pendapat yang paling unggul (al qawl al-

\footnotetext{
${ }^{10}$ Muhammad Hasyim Asy'ari, Risalah Ahl Al-Sunah Wa Al-Jamaah: Fi Hadits Al-Mauta Wa Asyrath Al-Sa'at Wa Bayan Mafhum AI-Sunah Wa Al-Bid'ah (Jakarta: LTM PBNU dan Pesantren Ciganjur, 2011)

${ }^{11}$ Ibid.

${ }^{12}$ Muslim (1718) dan diriwayatkan oleh al Bukhari secara muállaq dalam Kitab al Buyu’Bab An Najsy (4/356. Al Fath) dan Kitab al I'tishom bil Kitab Wa as Sunnah Bab Idza ljtahada al 'Amil au Hakim fa Akhtho'a (13/317, Fath)

${ }^{13}$ H.R Bukhari (2697)

${ }^{14}$ Muhammad Hasyim Asy'ari, Risalah Ahl Al-Sunah Wa Al-Jamaah, Hlm. 6
} 
mu'tamad) akhirnya dipakai sebagai rujukan memutuskan status muhdhathah tersebut." $^{15}$

Untuk menentukan status bid'ah pada suatu muhdhathah, dibutuhkan terlebih dahulu analisis teks al-sunnah berdasarkan kaidah kaidah musthalahul hadist yang telah dibakukan oleh generasi pendahulu (salafuna shalih), termasuk para mujtahid. Pendapat tentang status bid'ah baru akan diterima, setelah melalui analisis mendalam terhadap teks hadist yang dijadikan sebagai rujukan. Selain itu, apakah muhadhathah itu pernah dipraktikkan oleh generasi salaf atau tidak seharusnya ditetapkan secara proporsional. Muhdhathah yang belum pernah dilakukan oleh generasi salaf, selama tidak ada pelarangan dan memiliki argument syari'at tidaklah termasuk bid'ah. Ini berarti, muhdhathah yang tidak pernah dilakukan oleh generasi salaf tidak seluruhnya adalah bid'ah. Karena bisa jadi, ada kondisi-kondisi historis tertentu yang memungkinkan muhdhathah belum pernah dilakukan.

Pendapat Kiayi Hasyim ini, sama persis dengan pernyataan Imam Syafi'i sebagaimana ditegaskan oleh al-Gimari dalam Itqan al-sin'ah fitahqiqma'na bid'ah, Imam Syafi'i menyatakan: ${ }^{16}$

"setiap sesuatu yang mempunyai dasar dari dalil-dalil syara, maka bukan termasuk bid'ah meskipun belum pernah dilakukan oleh salaf.Karena sikap mereka yang meninggalkan hal tersebut terkadang karena uzur yang terjadi pada saat itu atau karena ada amaliyah lain yang lebih utama dan atau barangkali hal itu belum diketahui oleh mereka"

Lebih lanjut menurut pendapat Kiai Hasyim:

"Penentuan status bid'ah pada muhdhathah tertentu harus dirinci berdasarkan klasifikasi status hukum dalam syariat Islam yaitu wajib, sunnah, haram, makruh dan mubah. Selama terdapat argumentasi dan dalil yang dapat dijadikan sebagai ilhaq, terhadap penentuan status muhdhathah maka tidak berstatus bid'ah. Sebaliknya jika dengan menggunakan metode ilhaq dan tidak ditemukan argumen maupun dalilnya maka status muhdhathah adalah bid'ah secara otomatis. ${ }^{17}$

Dengan menggunakan metode ilhaq (proses analogi) ini, maka bisa jadi muhdhathah memiliki status bid'ah yang bermacam. Terdapat muhdhatahah yang berstatus bid'ah wajibah, mandumah, namun juga terdapat status diharamkan (mahrumah) dan tersesat. Dengan mengutip al-Sabhiri dalam sarah Arbain Nawawi, Kiai Hasyim menegaskan, terhadap hadist nabi yang mengatakan: "barang siapa menciptakan suatu perkara yang baru datang dalam agama atau melindungi orang yang menciptakan perkara yang baru tersebut maka baginya laknat Allah".

\footnotetext{
${ }^{15}$ Ibid

${ }^{16}$ Abdullah Muhammad Al-Ghimari. Itqan al-Shan'ah fi Tahqiq Ma'na Bid'ah. (Beirut: 'Alam al-Kutub, 2006).

${ }^{17}$ Ibid. Hasyim Asy'ari.
} 
Berdasarkan konsep bid'ah yang telah dijelaskan di atas, dapat diketahui bahwa tidak bisa serta merta menganggap suatu yang baru yang masih berstatus muhdhathah sebagai bid'ah, karena untuk menghukumi sesuatu harus mengetahui dan memahami alasannya terlebih dahulu. Hasyim Asy'ari dalam pemahamannya tentang bid'ah menyebutkan bahwa tidak semua yang baru dalam agama itu merupakan suatu yang sesat. Hal ini sejalan dengan pendapat imam Syafi'i yang menyebutkan bahwa setiap yang baru yang tidak pernah dilakukan oleh Rasul SAW dan salaf shalih tidak semuanya sesat, asalkan hal tersebut tidak bertolak belakang dengan al-Qur'an dan al-Sunnah. Bisa jadi hal yang baru dalam agama yang tidak pernah dilakukan oleh salaf shalih dikarenakan ada uzur yang membuat perbuatan seperti Tahlilan, Dzikir bersama, Istighatsah, Maulid Nabi dan Nisyfu Sya'ban tidak pernah dilakukan. Uzur tersebut bisa berupa karena mereka belum tahu dan juga terkait dengan kondisi social pada saat itu, hal ini mengindikasikan bahwa letak geografis dan sosio kultural sangat berpengaruh.

Tradisi Islam yang dibangun oleh Rasulullah dan para sahabat tidak semua bersifat universal, melainkan banyak yang temporal dan kondisional. Dalam hal ini Yusuf alQardhawi menyebutkan "mâ buniya min al-hadist alâ zhuruf zamâniyah wa alâ uruf zamân". Oleh karena itulah, sebagai seorang muslim yang menjunjung tinggi al-Qur'an dan al-Sunnah kita tidak boleh bersikap ekslusif dan menganggap bahwa tradisi-tradisi yang sudah bersinergi dengan ajaran islam itu disebut sebagai bid'ah dan bid'ah itu menunjukan kesesatan sedangkan yang sesat itu tempatnya di Neraka.

Mengenai hal tersebut, Dadang Syaripudin menjelaskan: ${ }^{18}$

"Dalam hal tradisi-tradisi yang tidak terdapat atau tidak dikenal sama sekali dalam sejarah dan kebudayaan islam Arab, maqashid al syariah untuk sementara ini merupakan satu pendekatan alternatif yang paling tepat. Karena pendekatan maqashid al syariah tidak hanya dapat ditunjukkan kepada perintah dan larangan pembuat syari'ah (dalam hal ini Rasulullah), tetapi juga bisa ditunjukan pada halhal yang tidak dipersoalkan sama sekali oleh Rasulullah. Dengan kata lain, dalam persfektif maqashid syariah, tidak serta merta segala sesuatu yang tidak terjadi dan atau tidak dilakukan oleh Rasulullah menjadi terlarang adanya. Sebagaimana pula tidak semua hal yang dikerjakan atau diperintah oleh Rasulullah tidak dapat dilakukan secara persis pada saat ini. Persoalannya adalah bagaimanakah dan kenapa Rasullullah SAW itu diam; tidak mau mengeluarkan perintah atau melarangnya apalagi melakukannya. Apakah diamnya itu karena suatu kemestian sekalipun ada tuntutan sesuai dengan pengetahuan, cara pandang dan kebijakannya atau karena memang tidak ada tuntutan? Jika diamnya itu sebagai suatu kemestian maka hal itu memang terlarang. Akan tetapi jika diamnya itu karena tidak ada tuntutan berbuat atau memerintah dan melarang belum tentu terlarang. Dalam hal ini terlarang atau tidaknya ditentukan oleh kemaslahatan atau kemafsadathan yang terkandung dalam atau yang diakibatkan oleh suatu tradisi." 
Sehingga dalam perspektif ini, tahlilan, dzikir bersama, istighashah, Maulid Nabi dan Nisfu Sya'ban merupakan tradisi Islam di yang tidak dikenal dalam tradisi Islam Arab, khususnya pada masa Rasulullah SAW Jika tradisi-tradisi tersebut merupakan kerusakan (mafsadath) maka jadi terlarang, tetapi sebaliknya jika mengandung kemaslahatan atau akan menimbulkan kemaslahatan maka menjadi mubah, sunnah atau bahkan wajib. ${ }^{19}$

Dengan penjelasan bid'ah seperti di atas, Hasyim Asy'ari kemudian menyatakan, bahwa tahlilan, dzikir bersama, isthigatshah, maulid nabi dan nisfu sya'ban bukanlah bid'ah yang sesat. Hal ini berdasarkan kaidah Al-Muhafadzotu 'alaa Oodimi As-Shalih Wa Al-Akhdu 'alaa Jadidi Al-Ashlah, kaidah ini sangat relevan pada saat ini, mengingat banyak sekali tradisi dan budaya yang berkembang.

Pemahaman bid'ah dan makna tradisi di atas erat kaitannya dengan bagaimana Islam menyebar luas di Indonesia, ini menjadi bukti bahwa penyampaian ajaran Islam di Indonesia sangat sukses. Artinya tak lepas dari metode yang dipakai para Wali penyebar Islam di Indonesia yang langsung bersinggungan dengan budaya-budaya lokal khas Hindu dan Budha. Untuk itu para Wali menyampaikan Syari'at Islam di Indonesia dengan metode Akulturasi budaya atau meminjam istilah K.H. Abdurrahman Wahid (Gus Dur) disebut sebagai Pribumisasi Islam.

Konsep tentang bid'ah menurut Hasyim Asy'ari, merupakan suatu teori untuk menjadikan umat Islam Indonesia lebih menjunjung tinggi toleransi dan mengedepankan syariat agar tidak terjadi kesalahpahaman sehingga memunculkan konflik antara umat Islam itu sendiri.

\section{Relevansi Hukum Islam dengan Adat Masyarakat Islam di Indonesia}

Islam yang tumbuh dan berkembang di Indonesia jauh berbeda dengan Islam yang pertama kali muncul di tanah Arab. Islam sebagai agama rahmatan lil alamin merupakan anugrah yang luar bisa dari Allah SWT, karena dengan lahirnya agama Islam yang dibawa oleh Nabi Muhammad SAW membawa berkah dan nikmat untuk seluruh alam.

Sebagaimana Allah SWT berfirman dalam Q.S al-Baqarah ayat 208:

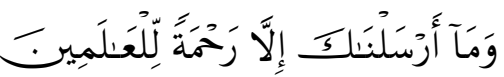

"...dan tiadalah Kami mengutus kamu, melainkan untuk (menjadi) rahmat bagi semesta alam."

Islam dengan segala ketentuan dan aturan yang dibawanya yang tercantum dalam al-Qur'an dan al-Sunnah merupakan aturan dasar kehidupan manusia di seluruh dunia. Hal ini menunjukkan bahwa adanya elastisitas dan flesksibilitas yang dibawa oleh aturan Agama Islam yaitu yang disebut dengan Syari'at. ${ }^{20}$

\footnotetext{
${ }^{19}$ Ibid. Dadang Syaripudin.

${ }^{20}$ Raihan Putry, Kepemimpinan Perempuan dalam Persfektif Islam, Jurnal Mudarrisuna, Volume 4 Nomor 3, Desember 2015, hlm. 626
} 
Islam masuk dan berkembang di Indonesia tidak langsung dari Arab, tetapi melalui India dan Persia terlebih dahulu. ${ }^{21}$ Itu berarti secara historis Islam di Indonesia tidak hanya dipengaruhi oleh budaya dan tradisi lokal, namun juga oleh Islam India, Persia dan Arab. Setelah Islam ditransmisikan dari generasi ke generasi serta kepada masyarakat non Arab maka lahirlah tradisi-tradisi Islam yang beragam. Sesuai dengan adagium shalih li kull zaman wa makan, bahwa Islam memiliki kapasitas untuk menampung kemajemukan yang menjadi ciri khas kehidupan masyarakat manusia. ${ }^{22}$ Terkait dengan penafsiran, Dadang Syaripudin lebih lanjut menyatakan bahwa :

"...produk penalaran hukum (istinbāth al-ahkām) dan lebih-lebih dalam penerapannya (tathbīq al-ahkām) pada satu ruang dan waktu tertentu, tidak bisa digugurkan oleh produk berikutnya, al-ljtihād la Tasqut bi al-ljtihād. ${ }^{23}$ Namun untuk kepentingan pemahaman dan penerapan dalam ruang dan waktu yang berbeda, tuntutan dilakukannya pemilahan adalah suatu kemestian."

Tradisi dan kebudayaan yang dikemas dalam adat di Indonesia merupakan hal yang harus diperhatikan dalam menjunjung tinggi Syari'at Islam. Jangan sampai Islam yang sudah mengakomodir nilai-nilai dan tradisi Indonesia ternodai dengan suatu yang salah menurut syariat. Ritual dalam suatu upacara keagamaan (Islam) jangan sampai dicampuri oleh sesuatu yang bertolak belakang dengan al-Qur'an dan al-Sunnah.

Dengan memahami makna bid'ah dan mengetahui tradisi dan kebudayaan Indonesia jelaslah bahwa Islam hadir dan berkembang bukan dengan peperangan melainkan dengan cara damai. Banyak tradisi-tradisi yang dilakukan umat muslim Indonesia jelasjelas perbuatan bid'ah tentunya bid'ah hasanah. Meskipun Allah SWT telah berfiman dalam al-Qur'an surat Al-Maidah ayat 3.

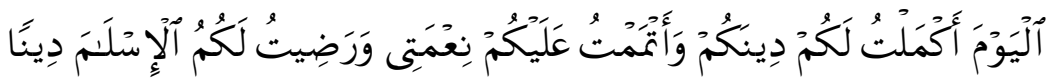

"pada hari ini telah Kusempurnakan untuk kamu agamamu, dan telah Kucukupkan kepadamu nikmat-Ku, dan telah Ku-ridhai Islam itu Jadi agama bagimu..."

Ayat di atas menunjukkan tentang kelengkapan dan kesempurnaan syariat serta kecukupannya dalam segala hal yang mana mereka diperintahkan untuk mengabdi kepada-Nya. Melihat konteks kekinian banyak amalan-amalan yang tidak pernah dilakukan oleh Rasulullah dan salaf shalih, tetapi bukan berarti mengingkari apa yang Allah jelaskan dalam ayat di atas. Tidak ada yang tahu apakah yang dilakukan oleh masyarakat Islam di Indonesia merupakan hal yang terlarang, wa allah a'lam.

Hal tersebut membuktikan bahwa Islam di Indonesia sama sekali berbeda dengan Islam ala Timur Tengah. Dengan penuh kompromi dan melalui dakwah bernuansa

\footnotetext{
${ }^{21}$ Uka Tjandrasasmita. Sejarah Nasional Indonesia III, (Jakarta: PN Balai Pustaka, 1984) , hlm. 200

${ }^{22}$ Abdul Mustaqim, Epistemologi Tafsir Kontemporer, (Yogyakarta: LKIS Yogyakarta, 2010) HIm. 54

${ }^{23}$ Al-Qaradhawi, Syari'áh al-Islá Shálihah li alTathbiq fi Kulli Zamán wa Makán, cet v, (Kairo: Maktabah Wahbah, 1997), hlm. 108-112
} 
hikmah tidak dengan cara memaksa apalagi membunuh, dakwah para wali dan ulama pada akhirnya bisa diterima dengan baik oleh pemeluk agama di Indonesia. Dengan begitu penulis merasa tradisi-tradisi seperti tahlilan, istighatsah, maulid nabi,nisfu sya'ban dan dzikir bersama harus tetap dilestarikan dalam rangka dakwah Islam yang penuh dengan hikmah dan tentunya bernuansa Indonesia.

Islam sama sekali tidak menuntut para penganutnya untuk tampil serba beda dengan keumuman masyarakat. Rasullullah pun diutus dengan budaya Arab, namunjuga Islam tidak sebaliknya menerima budaya lokal yang secara syariat bertolak belakang dengan al-Qur'an dan al-Sunnah. ${ }^{24}$ Islam mengharuskan bersikap kritis terhadap tradisi, sebagaimana firman Allah SWT dalam Q.S al-Isra, 17: 36 yang berbunyi:

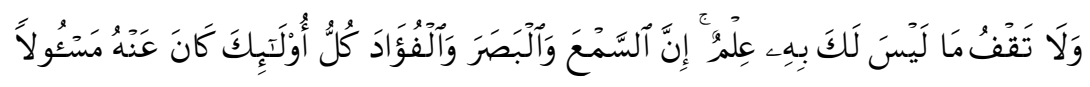

"dan janganlah kamu mengikuti apa yang kamu tidak mempunyai pengetahuan tentanganya. Sesungguhnya pendengaran, penglihatan dan hati, semuanya itu akan diminta pertanggungan jawabnya."

Sikap kritis inilah yang mendukung terwujudnya transformasi budaya yang terwarnai oleh ajaran Islam. Kebhinekaan dalam masyarakat harus diarahkan kepada terbentuknya kesatuan masyarakat, budaya, dan agama. Untuk mencapai hal tersebut maka konsep keberagaman yang ideal adalah ketika nilai agama itu melebur ke dalam nilai-nilai budaya. Jika tidak, maka dapat dikatakan bahwa pemahaman agamanya belum utuh dan mengakar.

\section{Simpulan}

Bagi Kiayi Hasyim tidak semua muhadast berstatus bid'ah dan sesat selama ia bersandar pada syariat yang digali dengan pendekatan dan metode yang telah diterima, seperti metodologi qiyas dalam istinbāth al-ahkām. Dengan demikian pengkategorian bid'ah terhadap sesuatu yang muncul belakangan tidak dapat dilakukan secara tekstual namun harus dilakukan dengan pendekatan yang menyeluruh. Sejalan dengan pandangan tersebut, penulis merasa tradisi-tradisi seperti tahlilan, dzikir bersama, istighatsah, maulid nabi dan nisfu sya'ban harus tetap dilestarikan dalam rangka dakwah Islam yang penuh dengan hikmah dalam nuansa budaya Indonesia.

\section{Daftar Pustaka}

A. Sihabuddin. 2013. Membongkar Kejumudan: menjawab tuduhan-tuduhan salafi wahhabi, Jakarta : Noura Books..

Abas, Sirajudin. 2004. 40 Masalah Agama, Jilid I-IV. Jakarta : Pustaka Tarbiyah.

${ }^{24}$ Mujamil Qomar, Ragam Identitas Islam di Indonesia dari Persfektif Kawasan, Jurnal Episteme, Volume 10 No. 2 Desember 2015 hlm. 317-352 
Abdusshomad, Muhyiddin. 2004. Fiqh Tradisionalis (jawaban berbagai persoalan keagaamaan sehari-hari), Malang : Pustaka Bayan.

Abdusshomad, Muhyiddin. 2006. Fiqh Tradisionalis (jawaban berbagai persoalan keagaamaan sehari-hari. Surabaya : Khalista.

Ali, Mahrus. 2008. Mantan KiaiNU Meluruskan Ritual-ritual KiaiAhliBid'ah yang Dianggap Sunnah. Jawa Tengah : Laa Tasyuk Press.

Al-Ghimari, Abdullah Muhammad. 2006. Itqan al-Shan'ah fi Tahqiq Ma'na Bid'ah. Beirut: 'Alam al-Kutub.

Fatah, Abdul. 2006. Tradisi Orang-orang NU. Yogyakarta : LKIS,.

Hadisutrisno, Budiono. 2009. Islam kejawen, Yogyakarta : Eule Book.

Khaeruman, Badri. 2010. Persatuan Islam Sejarah Pembaruan Pemikiran (KembaliKepada

al-Qur'an dan al-Sunnah, Forum Alumni Pondok Persatuan Islam (FAPPI). Bandung.

Khuluq, Lathiful, 2000. Fajar Kebangunan Ulama: Biografi K.H. Hasyim Asyári. Yogyakarta : LKiS.

Ma'arif, Samsul. 2011. Mutiara-Mutiara Dakwah K.H Hasyim Asy'ari, Jakarta : Kanza Publishing.

Madjid, Nurcholis. 2008. Islam Kemodernan dan Keindonesiaan, Bandung : Mizan. Muhibbin Zuhri, Achmad. 2010. PemikiranK.HM. Hasyim Asy'ari Tentang Ahl AL-Sunnah Wa AL-Jamaah, Surabaya : Khalista.

Mustaqim, Abdul. 2000. Epistemologi Tafsir Kontemporer, Yogyakarta : LKIS Yogyakarta Mutawalli Hammadah, Abbas. 1989. Sunnah Nabi Kedudukannya Dalam al-Qur'an, Bandung : Gema Risalah Press..

Muzadi, Muchid, 1994. NU dalam Perspektif Sejarah dan Ajaran: Refleksi 65 Tahun Ikut NU. Surabaya: Khalista.

Subhani, Ja'far. 2004. Kupas Tuntas Masalah Bid'ah. Jakarta : PT Lentera Basritama.

Sukardi, Heru. 1983. Kiayi Hasyim Asy'ari, Riwayat Hidup dan perjuangannya. Jakarta.

Sukarnawadi. 1996. Meluruskan Bid'ah. Surabaya : Dunia Ilmu Ofset..

Syaripudin, Dadang. 2003. Tradisi islam Nusantara: Dialektika IslamDan Pluralitas Tradisi Nusantara, Bandung.

Tjandrasasmita, Uka. 1984. (Ed) Sejarah Nasional Indonesia III. Jakarta : PN Balai Pustaka Yahya A. Muhaimin. 1992, "Budaya Politik dan Pembangunan Hukum Nasional", dalam Politik Pembangunan Hukum Nasional. Yogyakarta: UII Press.

Putry, Raihan, 2015. Kepemimpinan Perempuan dalam Persfektif Islam, Jurnal Mudarrisuna, Volume 4 Nomor 3, Desember 2015

Qaradhawi, Al-. 1997. Syari'áh al-Islá Shálihah lialTathbiqfiKulli Zamán wa Makán, cet v, Kairo: Maktabah Wahbah.

Mujamil Qomar, Ragam Identitas Islam di Indonesia dari Persfektif Kawasan, Jurnal Episteme, Volume 10 No. 2 Desember 2015 hlm. 317-352 